\title{
Lip and Oral Cavity Cancer TNM Finding v7
}

National Cancer Institute

\section{Source}

National Cancer Institute. Lip and Oral Cavity Cancer TNM Finding v7. NCI Thesaurus. Code C88938.

A finding about one or more characteristics of lip and oral cavity cancer, following the rules of the TNM AJCC V7 classification system. Nonepithelial tumors such as those of lymphoid tissue, soft tissue, bone, and cartilage are not included in this classification. (from AJCC 7th Ed.) 